\title{
Strawberry yield efficiency and its correlation with temperature and solar radiation
}

\author{
Pedro Palencia ${ }^{1}$; Fátima Martínez²; Juan Jesús Medina ${ }^{3}$; José López-Medina² \\ ${ }^{1}$ Universidad de Oviedo, Esc. Politécn. de Mieres, Depto. Biología de Organismos y Sistemas, C/Gonzalo Gutiérrez Quirós s/n, 33600 \\ Mieres, Spain; palencia@uniovi.es; ${ }^{2}$ Universidad de Huelva, Depto. Ciencias Agroforestales, E.T.S.I. 'La Rábida' 21819, Palos de la \\ Frontera, Huelva, Spain; fatima.martinez@dcaf.uhu.es; medina@uhu.es ${ }^{3}$ IFAPA, Consejería de Agric. y Pesca, Junta de Andalucía \\ 21800, Moguer, Huelva, Spain; juanj.medina@juntadeandalucia.es
}

\begin{abstract}
The impact that future climatic conditions will have on agricultural productivity depends on the sensitivity to each environmental factor and relative changes in temperature, precipitation and UV-B radiation. The strawberry (Fragaria x ananassa) is a microclimatic crop cultivated almost worldwide and Spain is the world's second-largest strawberry producer after the USA. Strawberry production in Huelva has been affected by climate change in recent decades. Temperature and solar radiation are primary environmental factors controlling short-day strawberry plant growth and development. Temperature is a limiting factor in crop productivity. We assessed the effect of variations in temperature and solar radiation on strawberry production and crop cycle duration. The study was carried out in commercial strawberry fruit production fields in the province of Huelva (Spain's southwestern coast). Fresh plants of cv. Camarosa were cultivated from October to June. The resulting crop was recorded weekly in the production field: early and total strawberry productions ( $\mathrm{g}$ / plant), were recorded from January to March and from January to May, respectively. Data revealed that between early production and temperature $\left(\mathrm{R}^{2}=0.86\right)$ and between early production and solar radiation $\left(R^{2}=0.73\right)$ there was a linear relationship. However, total production and temperature $\left(\mathrm{R}^{2}=0.69\right)$ and total production and solar radiation $\left(\mathrm{R}^{2}=0.69\right)$ were related by a quadratic relationship. Our estimates suggest that strawberry production could be affected by climate change. Due to the relationship between yield and temperature, and between yield and solar radiation, climate change scenarios were found to result in reductions in crop cycle duration.
\end{abstract}

Keywords: Fragaria $\mathrm{x}$ ananassa, environmental factors, fruit yield, climate change, 'Camarosa'.

\section{RESUMEN}

Eficiencia de la producción de fresa y su correlación con la temperatura y la radiación solar

El impacto que las condiciones climáticas futuras tendrán en la productividad agrícola, depende de la sensibilidad de cada factor ambiental y de los cambios relativos en la temperatura, precipitación y radiación UV-B. La fresa (Fragaria $x$ ananassa) es un cultivo microclimático que se cultiva en casi en todo el mundo y, España es el segundo productor de fresa después de los EE.UU. La producción de fresa en Huelva se ha visto afectada por el cambio climático en las últimas décadas. La temperatura y la radiación solar son los principales factores ambientales que influyen en el crecimiento y desarrollo de las plantas de fresa de día corto. La temperatura es un factor limitante en la productividad del cultivo. El objetivo de este trabajo fue evaluar el efecto de las variaciones en la temperatura y la radiación solar sobre la producción de fresas y la duración del ciclo de cultivo. El estudio se llevó a cabo en campos de producción comercial de fresa en la provincia de Huelva (costa suroeste de España). Se utilizó planta fresca de la variedad Camarosa. Las plantas fueron cultivadas desde octubre hasta junio. La producción fue cosechada semanalmente. Se tomaron datos de la producción temprana (desde enero hasta marzo) y total (desde enero hasta mayo) expresado en gramos por planta. Los datos revelaron que entre la producción temprana y la temperatura $\left(\mathrm{R}^{2}=0,86\right)$ y entre la producción temprana y la radiación solar $\left(\mathrm{R}^{2}=0,73\right)$ se observó una relación lineal. Sin embargo, la producción total y la temperatura $\left(\mathrm{R}^{2}=0,69\right)$ y la producción total y la radiación solar $\left(\mathrm{R}^{2}=0,69\right)$ fueron relacionadas por una relación cuadrática. Nuestras estimaciones sugieren que la producción de fresas podría verse afectada por el cambio climático. Debido a la relación entre el rendimiento y la temperatura, y entre la radiación solar y el rendimiento, los escenarios de cambio climático podrían dar lugar a reducciones en la duración del ciclo de cultivo.

Palabras claves: Fragaria $\mathrm{x}$ ananassa, factores ambientales, producción de fruta, cambio climático, 'Camarosa'.

\section{(Recebido para publicação em 3 de abril de 2012; aceito em 7 de fevereiro de 2013)}

(Received on April 3, 2012; accepted on February 7, 2013)

\begin{abstract}
A griculture was one of the first sectors to be studied in terms of the potential impact of climate change. Many alternatives have been proposed to enable growers to minimize losses in yield. There are many pathways by which climate-related factors can impact on food safety including: changes in
\end{abstract}

temperature and precipitation patterns, increased frequency and intensity of extreme weather events.

Strawberry (Fragaria x ananassa), a small fruit crop and a hybrid of two highly variable octoploid species, has adapted to extremely different environmental conditions (Rieger,
2005). The strawberry is grown throughout the world and cultivation and production increase each year. The strawberry is an important crop worldwide in terms of both its commercial value and the role it plays in rural economies. Spain is the Europe's leading producer of strawberries and it 
is estimated that there are about 6,500 ha under cultivation with an average annual production of over 24,9410 tons. The European Network for Strawberry Cultivar Evaluation (COST ACTION, UE, 836 programme) has shown that its pattern of productivity (yield capacity) and fruit quality can be affected by the interaction of factors such as altitude, latitude, soil characteristics, type of cultivation system, day length, and temperature (Krüger et al., 2004).

As strawberry fruit bearing and maturity occur in a short time (2040 days after pollination) and also strawberries have shallow root systems (the plants are growing via stolons), light and water management are critical for achieving high yield and fruit quality of strawberries (Li et al., 2010). Many alternatives have been proposed to growers aimed at minimizing losses in yield. Temperature increases and changes in rainfall patterns have an impact on the persistence and patterns of the occurrence of bacteria, viruses, parasites and fungi and the patterns of their corresponding foodborne diseases (Tirado et al., 2010). Such changes also have an impact on microbial ecology and growth, plant physiology and host susceptibility which may result in the emergence, redistribution and changes in the incidence and intensity of plant and pest infestations; all of which could impact on foodborne diseases (FAO, 2008). According to studies carried out by the Intergovernmental Panel on Climate Change (IPCC), average temperatures will increase between $1.4^{\circ} \mathrm{C}$ and $5.8^{\circ} \mathrm{C}$ by the end of this century, based on modelling techniques that incorporated data from ocean and atmospheric behaviour (IPCC, 2007).

The most significant factors for heat stress-related yield loss in crops include shortening of developmental phases induced by high temperature, reduced light perception over the shortened life cycle and perturbation of the processes associated with plant carbon balance (Barnabás et al., 2008). It is necessary to understand the relationships between solar radiation, temperature, soil water and strawberry quality and fruit yield. In addition, plant and soil functions are often encountered for underlying environmental variables. Light intensity seems of special importance to strawberry cultivars; fruit maturity is the main index for sorting and harvesting (Xu \& Zhang, 2007). Solar radiation and temperature distribution can vary significantly with different topographic features such as elevation aspect and slope (Li et al., 2001). Existing studies in the literature about the effect of ambient levels of UV radiation on the productivity of strawberry crops are scarce, although there are other jobs related to agricultural crops such as corn (Correia et al., 2005), wheat (Yao et al., 2007), tomato (Devanand et al., 2006) or lettuce (Krizek et al., 2005), among others. These studies didn't show clear evidence the effect of ultraviolet radiation on crops productivity.

Higher temperatures can increase the capacity of air to absorb water vapor and, consequently, generate a higher demand for water. Higher evapotranspiration indices could lower or deplete the water reservoir in soils, creating water stress in plants during dry seasons (Moretti et al., 2010). It is well documented that water stress not only reduces crop productivity but also tends to accelerate fruit ripening (Henson, 2008). Exposure to elevated temperatures can cause morphological, anatomical, physiological, and, ultimately, biochemical changes in plant tissues and, as a consequence, can affect the growth and development of different plant organs. Temperature is one of the most important factors affecting strawberry plant nutrient uptake (Li et al., 2010). Temperature is associated with strawberry flower bud induction, runner, meristem-tip and leaf variegation (Watson et al., 2002), and membrane phospholipids (Wang \& Lin, 2006). Temperature is of paramount importance in the establishment of a harvest index. High temperatures have the most impact on the final harvestable crop, as seen in cereals (Barnabás et al., 2008).

Radin et al. (2011) reported that an increase in average temperature of $3^{\circ} \mathrm{C}$ when comparing two different regions of production in the area of Brazil, made a difference in the number of fruits. High temperatures $\left(24-32^{\circ} \mathrm{C}\right)$ reduces strawberry flower formation and fruit quality (Klamkowski \& Treder, 2008). Temperature and solar radiation are primary environmental factors controlling short-day strawberry plant growth and development. High temperatures in the range of $28-30^{\circ} \mathrm{C}$ inhibited flower induction in shortday and neutral-day cultivars of $F$. $x$ ananassa and $F$. vesca (Okimura \& Igarashi, 1997). On the other hand, high temperatures are known to reduce fruit size and fruit weight in strawberries, but cultivar differences in the response to high-temperature stress during the reproductive stage up to second inflorescence growth have not been sufficiently reported. Likewise, high-temperature stress negatively affects the reproductive process in strawberries and plant response to hightemperature stress is cultivar-related in such responses (Ledesma et al., 2007). Higher than normal temperatures affect the photosynthetic process through the modulation of enzyme activity as well as the electron transport chain (Sage \& Kubien, 2007). The aim of this work was to assess the variation of temperature and solar radiation on strawberry production and crop cycle duration.

\section{MATERIAL AND METHODS}

The study was carried out in commercial strawberry fruit production fields around the village of Moguer $\left(37^{\circ} 17^{\prime} \mathrm{N}, 6^{\circ} 51^{\prime} \mathrm{W}, 35,35 \mathrm{~m}\right.$ altitude) on the southwestern coast of Spain, during the 2003-04, 2004-05 and 200506 seasons. This experimental site is a major high-tunnel strawberry production area in Spain with loamy sand soil with an organic matter content of between $0.4-0.6 \%$, and a pH of 6.7 to 7.1 . Beds were constructed with a tractor-mounted bed presser, and their dimensions were $30 \mathrm{~cm}$ (wide) by $60 \mathrm{~cm}$ (high) respectively. Simultaneously with bed pressing, a single drip line with a flow rate of $1.56 \mathrm{~L} / \mathrm{m}$ per hour and emitters every $30 \mathrm{~cm}$ were placed $5 \mathrm{~cm}$ deep on the bed centers; the beds were covered with polyethylene mulch, and 1,3 dichloropropene + chloropicrin (65:35, $\mathrm{v} / \mathrm{v}$ ) fumigant was injected $20 \mathrm{~cm}$ deep with four chisels per bed. The fumigant was applied on 16 September 2003, 
14 September 2004 and 6 September. 2005. Average soil temperatures during fumigation were between 25 and $29^{\circ} \mathrm{C}$. The beds were mulched with a black (1.4 m wide), virtually impermeable film (1.5 mil), which increases retention of volatile fumigants and exposure of soil pests to lethal fumes. High tunnels were built using semicircular steel bars $3.3 \mathrm{~m}$ in height at the tunnel apex and $8.3 \mathrm{~m}$ wide. These bars were mounted on $1.8 \mathrm{~m}$-long side support bars. Each high-tunnel had six beds and was covered with translucent polyethylene plastic, which allowed in $60 \%$ of the photosynthetic active radiation. Tunnels were covered on 26 November 2003,8 November 2004 and 8 November 2005.

Bare-root 'Camarosa' strawberry plants from commercial nurseries in Valladolid (Spain) were transplanted on 22 October 2003, 11 October 2004 and 17 October 2005. Transplants were placed in double rows per mulched bed and spaced $27 \times 22 \mathrm{~cm}$ apart between rows and plants. Transplanting came with intermittent drip application and microsprinkler irrigation during the first 10 days to ensure the cooling down of strawberry crowns. Conventional crop management techniques were followed, as recommended for strawberry production under plastic tunnels in the area (López-Aranda et al., 2002).

The study was repeated three times from 2003 to 2006 and a wintercultivation system was implemented each year. In this area, there are two different periods within the crop season: a cold early crop season (low temperatures and high relative humidity) between January and March (early production) and a warmer late crop season (high temperatures and low relative humidity) between April and May (late production).

The total marketable fruit yield (sum of early and late production) from 1 January to May 31 in $\mathrm{g} /$ plant was recorded weekly during the harvest. The early marketable fruit yield was recorded from January 1 to March 31 in $\mathrm{g} / \mathrm{plant}$. The strawberries were classified as first-class fruits: strawberries of good quality with colouring and shape characteristic of the variety. Some slight defects were permitted, provided these did not affect the general appearance of the produce, the quality, the keeping quality and presentation in the package: slight defect of shape, a white patch, not exceeding one tenth of the surface area of the fruit, slight superficial pressure marks. They must be practically soilfree. Second-class fruits were those strawberries that do not qualify for inclusion in the first class, but which satisfied the minimum requirements specified above. Some defects were permitted provided the strawberries retained their essential characteristics as regards the quality, the keeping quality and presentation: defects of shape, a white patch not exceeding one fifth of the surface area of the fruit, slight dry bruising not likely to spread, slight traces of soil (European Community legislation 843/2002). Second-class fruits (total fruit less first-class fruits) were measured in both early and total yield.

Meteorological data were taken from the Andalucia Institute of Agrometeorological Research for the station in Moguer $\left(37^{\circ} 08^{\prime} 52^{\prime}\right.$ 'N, $6^{\circ} 47^{\prime} 28^{\prime \prime} \mathrm{W}, 87,35 \mathrm{~m}$ altitude) located about $3 \mathrm{~km}$ from the strawberry fields. Temperatures were measured daily every 2 seconds and the average recorded every 24 hours. The radiation was measured every 10 seconds in units of watts $/ \mathrm{m}^{2}$ and passed $\mathrm{mJ} / \mathrm{m}^{2}$ day. The station is owned and maintained by the Andalusian Regional Government, and is part of the Agricultural and Environmental monitoring network. Different kinds of instrument are included in this network, from Skye model SP1110 pyranometer to Vaisala

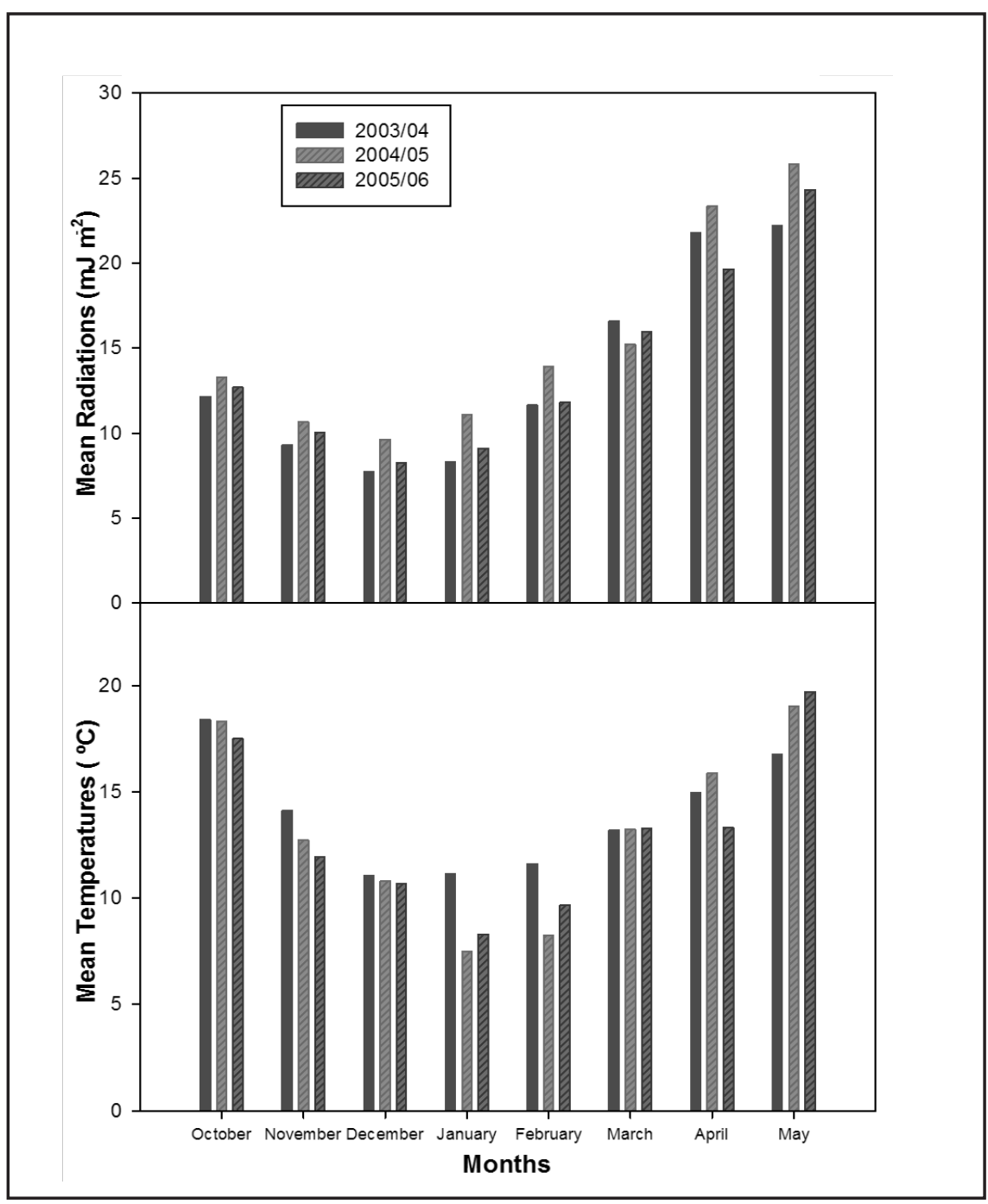

Figure 1. Mean temperatures and solar radiation for the years 2003-2006 (temperaturas minimas e radiação solar nos anos 2003-2006). Huelva, Espanha, Univers. de Huelva, 2003-2006. 
Table 1. Air temperatures, solar radiation, second-class fruit and total yield recorded each month during three crop cycles (2003-2006) [temperaturas do ar, radiação solar, produção total e de segunda categoria registrados mensalmente durante os três ciclos de cultivo (20032006)]. Huelva, Espanha, Univers. de Huelva, 2003-2006.

\begin{tabular}{|c|c|c|c|c|c|c|c|c|c|c|}
\hline & Year & October & November & December & January & February & March & April & May & Mean \pm SD \\
\hline \multirow{4}{*}{$\begin{array}{l}\text { Temperature } \\
\left({ }^{\circ} \mathrm{C}\right)\end{array}$} & $2003 / 04$ & 18.4 & 14.1 & 11.1 & 11.1 & 11.6 & 13.2 & 15.0 & 16.8 & $13.9 \pm 2.5$ \\
\hline & $2004 / 05$ & 18.3 & 12.7 & 10.8 & 7.5 & 8.3 & 13.3 & 15.9 & 19.0 & $13.2 \pm 4$ \\
\hline & $2005 / 06$ & 17.5 & 12.0 & 10.7 & 8.3 & 9.7 & 13.3 & 13.3 & 19.7 & $13.1 \pm 3.6$ \\
\hline & $\begin{array}{l}\text { Mean } \pm \text { SD } \\
2003-06\end{array}$ & $18.1 \pm 0.4$ & $12.9 \pm 0.9$ & $10.9 \pm 0.2$ & $9.0 \pm 1.5$ & $9.9 \pm 1.4$ & $13.2 \pm 0$ & $14.7 \pm 1.1$ & $18.5 \pm 1.3$ & $13.4 \pm 0.6$ \\
\hline \multirow{4}{*}{$\begin{array}{l}\text { Radiation } \\
\mathrm{mJ} / \mathrm{m}^{2}\end{array}$} & $2003 / 04$ & 12.1 & 9.3 & 7.7 & 8.3 & 11.6 & 16.6 & 21.8 & 22.2 & $13.7 \pm 5.4$ \\
\hline & $2004 / 05$ & 13.3 & 10.6 & 9.6 & 11.1 & 13.9 & 15.2 & 23.3 & 25.8 & $15.4+5.6$ \\
\hline & $2005 / 06$ & 12.7 & 10.1 & 8.2 & 9.1 & 11.8 & 16.0 & 19.6 & 24.3 & $14.0 \pm 5.2$ \\
\hline & $\begin{array}{l}\text { Mean+SD } \\
2003-06\end{array}$ & $12.7 \pm 0.5$ & $10.0 \pm 0.5$ & $8.5 \pm 0.8$ & $9.5 \pm 1.2$ & $12.4 \pm 1$ & $15.9 \pm 0.6$ & $21.6 \pm 1.5$ & $24.1 \pm 1.5$ & $14.3 \pm 0.2$ \\
\hline \multirow{4}{*}{$\begin{array}{l}\text { Second-class } \\
\text { fruit } \\
\text { (g/plant) }\end{array}$} & $2003 / 04$ & 0.0 & 0.0 & 0.0 & 0.0 & 0.9 & 5.9 & 9.7 & 14.5 & $6.2 \pm 5.4$ \\
\hline & $2004 / 05$ & 0.0 & 0.0 & 0.0 & 0.2 & 2.3 & 12.4 & 25.7 & 44.9 & $17.1 \pm 16.6$ \\
\hline & $2005 / 06$ & 0.0 & 0.0 & 0.0 & 0.0 & 0.7 & 5.4 & 9.1 & 10.6 & $5.2 \pm 4.3$ \\
\hline & $\begin{array}{l}\text { Mean } \neq \text { SD } \\
2003-06\end{array}$ & 0.0 & 0.0 & 0.0 & $0.1 \pm 0.1$ & $1.3 \pm 0.7$ & $7.9 \pm 3.2$ & $14.8 \pm 7.7$ & $23.3 \pm 15.4$ & $9.5 \pm 5.6$ \\
\hline \multirow{4}{*}{$\begin{array}{l}\text { Total yield } \\
\text { (g/plant) }\end{array}$} & $2003 / 04$ & 0.0 & 0.0 & 0.0 & 2.4 & 91.9 & 197.7 & 340.5 & 364.9 & $199.5 \pm 146.7$ \\
\hline & $2004 / 05$ & 0.0 & 0.0 & 0.0 & 13.6 & 110.2 & 245.8 & 464.3 & 452.7 & $257.3+189.2$ \\
\hline & $2005 / 06$ & 0.0 & 0.0 & 0.0 & 11.4 & 101.2 & 250.1 & 243.1 & 203.5 & $161.9 \pm 107$ \\
\hline & $\begin{array}{l}\text { Mean } \pm \text { SD } \\
2003-06\end{array}$ & 0.0 & 0.0 & 0.0 & $9.1 \pm 4.8$ & $101.1 \pm 7.5$ & $231.2 \pm 23.7$ & $349.3 \pm 90.5$ & $340.3 \pm 103.2$ & $206.2 \pm 33.6$ \\
\hline
\end{tabular}

Table 2. Mean early and late production recorded each week during three crop cycles (2003-2006) [produção inicial e total registrados semanalmente durante os tres ciclos de cultivo (2003-2006)]. Huelva, Espanha, Univers. de Huelva, 2003-2006.

\begin{tabular}{|c|c|c|c|c|c|c|c|c|c|c|c|c|c|c|}
\hline & \multicolumn{14}{|c|}{ Early production (2003-06) } \\
\hline Week & 1 & 2 & 3 & 4 & 5 & 6 & 7 & 8 & 9 & 10 & 11 & 12 & 13 & 14 \\
\hline \multirow[t]{2}{*}{ Yield (g/plant) } & 0 & 0 & 4 & 8.5 & 9.5 & 21.4 & 33.9 & 31.1 & 16.8 & 38.2 & 50.9 & 72.9 & 58.3 & 112.5 \\
\hline & \multicolumn{14}{|c|}{ Late production (2003-06) } \\
\hline Week & 15 & 16 & 17 & 18 & 19 & 20 & 21 & 22 & 23 & & & & & \\
\hline Yield (g/plant) & 102 & 83.1 & 51.7 & 108.2 & 58.7 & 99.3 & 46.7 & 82.3 & 0 & & & & & \\
\hline
\end{tabular}

*First week: Crop cycle (2003/2004) between $29^{\text {th }}$ December 2003 to $4^{\text {th }}$ January 2004; Crop cycle (2004/2005) between $3^{\text {th }}$ January 2005 to $9^{\text {th }}$ January 2005; Crop cycle (2005/2006) between $2^{\text {nd }}$ January 2006 to $8^{\text {th }}$ January 2006 (ISO 8601) [*Primeira semana: Ciclo de cultivo (2003/2004 entre 29 de dezembro de 2003 e 4 de janeiro de 2004; Ciclo de cultivo (2004/2005) entre 3 e 9 de janeiro de 2005; Ciclo de cultivo (2005/2006) entre 2 e 8 de janeiro de 2006 (ISO 8601)].

model HMP45C temperature and relative humidity probe.

SPSS-18 and SigmaPlot-10 were used for statistical calculations and graphics. Significant differences were determined at $\mathrm{p} \leq 0.001$.

\section{RESULTS AND DISCUSSION}

Temperatures were significantly different in the three crop cycles measured. The temperature in May was important because it comes at the end of each crop cycle (Figure 1). There was a linear relationship between early production and temperature $\left(\mathrm{R}^{2}=0.86\right)$; and a quadratic relationship between total production and temperature $\left(\mathrm{R}^{2}=0.69\right)$. Model results suggest that optimum production strategies under current climate conditions are achieved using plant densities of 6.3 plants $/ \mathrm{m}^{2}$, showing $458.11 \mathrm{~g} / \mathrm{plant}$ between January and March (early accumulated production) and 1,090.05 $\mathrm{g} /$ plant between January and May (total accumulated production), as seen in Table 2. In high temperatures, the strawberry early yield increased to 17.8 g/plant (Figure 2).
Values of maximum air temperatures and radiation during the three crop cycles increased in April and May, being higher at the end of crop cycle (Table $1)$. The minimum air temperatures were measured between January and February. In relation to solar radiation, the values showed a progressive increase during the productive period, reaching the highest values $\left(28.82 \mathrm{Mj} / \mathrm{m}^{2}\right)$ at the end of the harvest (year 2004-2005). In relation to the second yield, higher values were obtained in the second crop cycle (2004-2005). The most important second-yield values were recorded in 


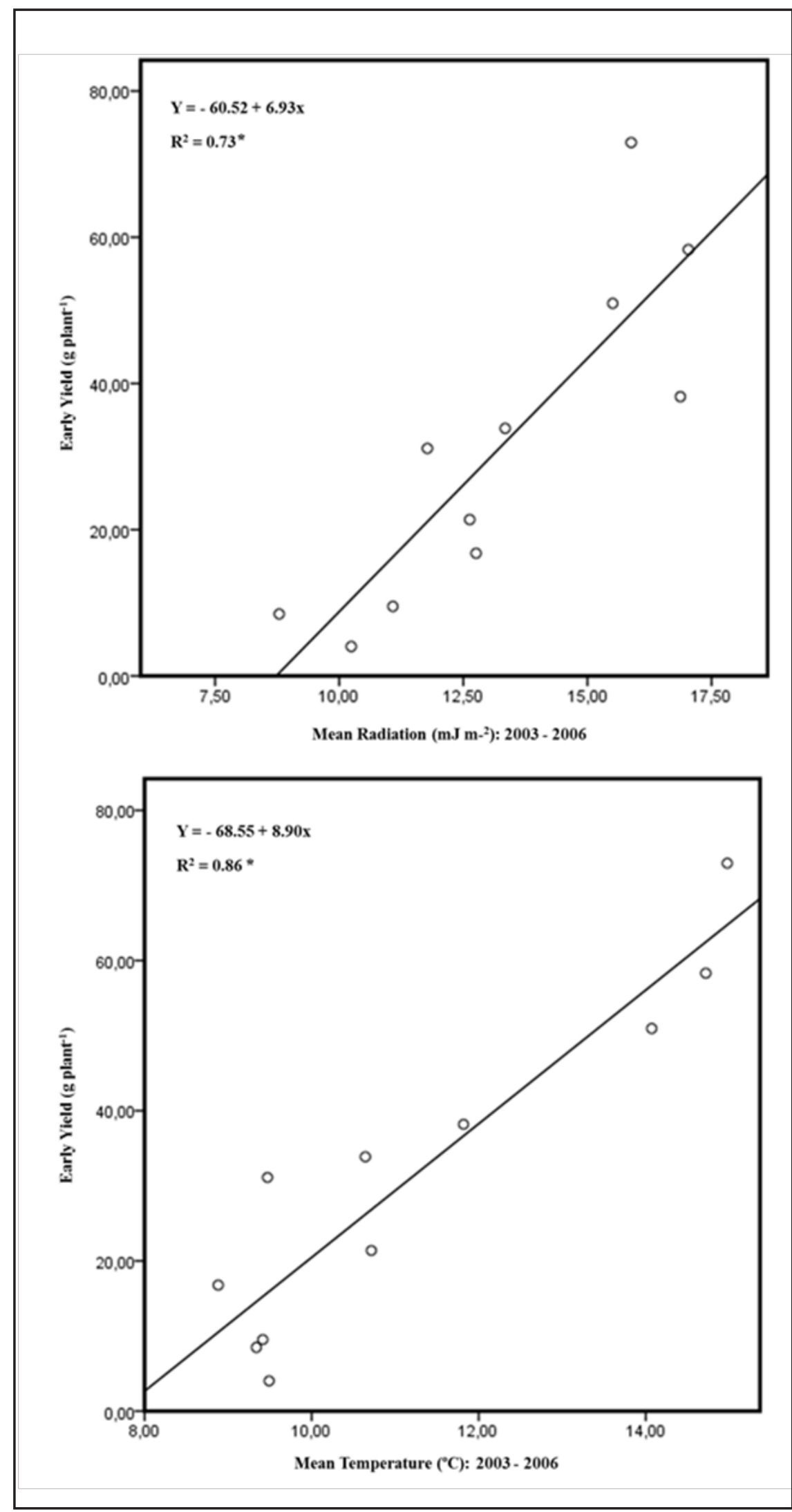

Figure 2. Statical early yield model used as related mean radiation and temperature for the years 2003-2006 (modelo estatístico da produção precoce em relação à media da radiação e da temperature, anos 2003-2006). Huelva, Espanha, Univers. de Huelva, 2003-2006. $\mathrm{NS}=$ non-significant; $* * * *$ significant at $\mathrm{p} \leq 0.05$ and $\mathrm{p} \leq 0.01$, respectively (ns= não significativo; $* ; *$ significativo a 5 e a $1 \%$, respectivamente).
May. In the second crop cycle (20042005) strawberry total yield increased in April and May compared to the other crop cycles evaluated. The yields were higher between April and May (late yield) than between January and March (early yield) (Table 1 ).

Maximum yield was obtained in the final week of March (112.54 g/plant, 14 weeks after planting). This occurred with a mean temperature of $15.96^{\circ} \mathrm{C}$ (Figure 2). Figure 1 shows that $13.24^{\circ} \mathrm{C}$ is the mean for March in the three years. These results are similar to those of Márquez (2008) which indicated that the ideal temperature for fructification is between $15^{\circ} \mathrm{C}$ and $20^{\circ} \mathrm{C}$. Maximum yield $(80 \mathrm{~g} /$ plant) will be obtained at $15^{\circ} \mathrm{C}<\mathrm{T}^{\mathrm{a}}<20^{\circ} \mathrm{C}$ (Figure 2). Total yield decreases with $\mathrm{T}^{\mathrm{a}}>20^{\circ} \mathrm{C}$ due to the high temperatures in the high tunnel. However, the sensitivity of the plants to high temperatures varies with the size and age of the plant. The effect of high temperatures on the increase in vegetative growth could be the reason for reductions in total yield. Reproductive development in plants is more sensitive to high temperatures than vegetative growth because plant fertility is considerably reduced as temperatures increase (McKee \& Richards, 1998).

The scenario for 2070 to 2100 is for a substantial temperature increase (IPCC, 2007). In this situation, the relationship between the yield and temperature could result in higher early production and in reductions in total yield.

Solar radiation was significantly different in the three crop cycles (2003-04, 2004-05 and 2005-06). Solar radiation was higher in the second crop cycle (2004-2005) than in the other crop cycles measured. In general, solar radiation was higher in March, April and May than in other months (Figure 1). There was a linear relationship between early production and solar radiation $\left(\mathrm{R}^{2}=0.73\right)$ (Figure 2); results suggested that the relationship between total production and solar radiation was a quadratic relationship $\left(R^{2}=0.69\right)$ (Figure $3)$. The early yield increased between 9 and $18 \mathrm{~mJ} / \mathrm{m}^{2}$. With high solar radiation, the strawberry early yield increased to $17.32 \mathrm{~g} /$ plant (Figure 2). In this sense, Kakani et al. (2003) suggested that the 


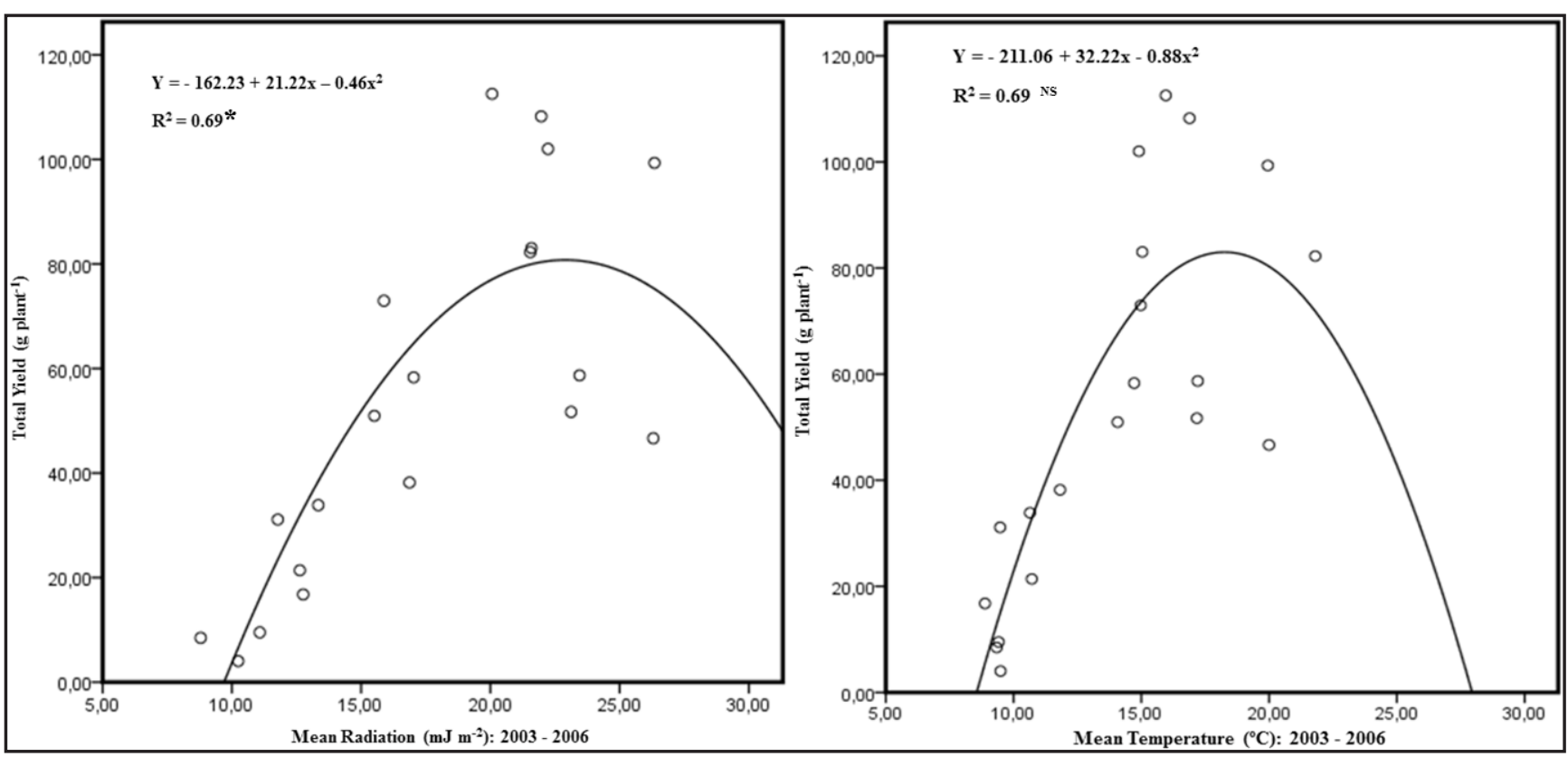

Figure 3. Statical total yield model used as related mean radiation and temperature for the years 2003-2006 (modelo estatistico da produção total em relação com a media da radiação e temperatura nos anos 2003-2006). Huelva, Espanha, Univers. de Huelva, $2003-2006$.

$\mathrm{NS}=$ non-significant; $* * * *$ significant at $\mathrm{p} \leq 0.05$ and $\mathrm{p} \leq 0.01$, respectively (ns $=$ não significativo; $* * * *$ significativo a 5 e a $1 \%$, respectivamente).

reviewed numerous studies that tried to assess the effect of radiation enhanced UV-B on the productivity of different crops, almost half showed negative effect, others didn't show changes and a small studies indicated increases in productivity. Also notes that there is a specific wide variability regarding the sensitivity to UV radiation $\mathrm{B}$. Li et al. 2002 and $\mathrm{Zu}$ et al. 2004 suggested similar results in other crops but not in strawberry crops, although strawberry fruit yield were negatively correlated with solar irradiance (Li et al., 2010).

Maximum yield was reached in the final week of March (112.54 g/plant, 14 weeks after planting) (Table 2). This occurs with a mean solar radiation of $20.07 \mathrm{~mJ} / \mathrm{m}^{2}$ (Figure 3). Figure 1 shows that maximum solar radiation was obtained in May. Maximum yield (80 g/plant) will occur with mean radiation at between $20 \mathrm{~mJ} / \mathrm{m}^{2}$ and 25 $\mathrm{mJ} / \mathrm{m}^{2}$ (Figure 3 ). Total yield decreases when mean radiation is higher than $25 \mathrm{~mJ} / \mathrm{m}^{2}$. The maximum point in the quadratic equation was 82.5 for mean radiation and 83.86 for mean temperature respectively (Figure 3).

High temperatures on the fruit surface caused by prolonged exposure to sunlight hasten ripening and other associated events. Strawberry fruit exposed to greater sunlight ripened faster. The relationship between high temperature and the rate of ripening could be argued as a factor in reduced crop cycle duration. These results are similar to those of Woolf et al. (1999), which indicated that the ripening of 'Hass' avocados was also affected by exposure to high temperatures during growth and development. For fruits exposed to direct sunlight, pulp temperatures reached $35^{\circ} \mathrm{C}$ and required 1.5 days longer to ripen than those grown in the shade. In recent years, observations from various world winemaking regions have provided evidence of modified vine development and fruit maturation patterns. Dates for budbreak, flowering and fruit maturity are now earlier in various regions (Mira de Orduña, 2010).

Our estimates suggest that strawberry cv. Camarosa production can be affected by climate change. Due to the relationship between the yield and temperature an increase in temperature will result in higher early production and in reductions in total yield (Palencia et al., 2009).

Temperature and solar radiation variation can affect production, and a rise in global temperatures can be expected to have significant impact on the crop cycle. The relationship between high temperatures and the rate of hasten ripening could explain the reductions in crop cycle duration.

The strawberry is widely cultivated around the world. However, it is a species that is susceptible to micro-climatic adaptation, since its morphoagronomical behaviour is influenced by the agroenvironment of the area of cultivation. Even if the present production methods in the different environmental conditions are efficient, they still need further optimization mainly to reduce their resource needs and losses to the environment as well as to increase the availability of high quality strawberry fruit in the market. In the same way, physiological and agronomic strategies such as different cultivation systems could decrease the effects of climatic changes on crop production and food quality.

The potential hazards of environmental temperatures and radiation for strawberry growth will depend on local circumstances, and efforts to understand the impact of variations in temperature radiation and other ongoing climatic changes on food 
crops are crucial for estimating food production in the future.

The requirements of future cultivation systems for the strawberry need to be discussed further to help deliver increased profitability to producers and increased availability of high quality fruits to consumers, as well as to minimise the negative impact on the environment and risks of damage related to climate change. The relation between high temperatures and early fruit maturation could explain the reduced crop cycle. In doing so, it is necessary not only to quantify the effects of climatic changes on crop production but also on crop cycle duration.

\section{REFERENCES}

BARNABÁS B; JÄRGEN K; FEHÉR A. 2008. The effect of drought and heat stress on reproductive processes in cereals. Plant, Cell \& Environment 31: 11-38.

CORREIACM; PEREIRA JMM; COUTINHO JF; BJÖRN LO; TORRES-PEREIRA JMG. 2005 Ultraviolet-B radiation and nitrogen affect the photosynthesis of maize: a Mediterranean field study. European Journal of Agronomy 22: 337-347.

DEVANAND LL; MUKHOPADHYAY S.; KRIZEK DT. 2006. Content of total phenolics acids in tomato (Lycopersicon esculentum Mill.) fruits as influenced by cultivar and solar UV radiation. Journal of Food Composition and Analysis 19: 771-777.

FAO 2008. Food safety and climate change. FAO conference on food security and the challenges of climate change and bioenergy. $<\mathrm{http}: / / \mathrm{www}$. fao.org/ag/agn/agns/files/HLC1_Climate_ Change_and_Food_Safety.pdf $>$

HENSON R. 2008. The rough guide to climate change $\left(2^{\text {nd }}\right.$ ed.). Penguim Books, London, $384 \mathrm{p}$.

IPCC. Climate change 2007. In: SOLOMON S; QIN D; MANNING M; CHEN Z; MARQUIS M; AVERYT KB; TIGNOR M; MILLER HL (eds). The physical science basis. Contribution of working group I to the fourth assessment report of the intergovernmental panel on climate change (996p.). Cambridge, United Kingdom: Cambridge University Press. ISO-8601 (1997). ftp://ftp.qsl.net/pub/ g1smd/8601v03.pdf.

KAKANI VG; REDDY KR; ZHAO D; SAILAJA
K. 2003 Field crop responses to ultraviolet-B radiation: a review. Agricultural and Forest Meteorology 120: 191-218.

KLAMKOWSKI K; TREDER W. 2008. Response to drought stress of three strawberry cultivars grown under greenhouse conditions. Journal of Fruit and Ornamental Plant Research 16: 179-188.

KRIZEK DT; CLARK HD; MIRECKI R M. 2005. Spectral properties of selected UV-blocking and UV-transmitting covering materials with application for production of high-value crops in high tunnels. Photochemistry and Photobiology 81: 1047-1051.

KRÜGER E; KRIEG R; INNERHOFER G; LATET G; LIETEN F, MACNAEIDHE F; EVENHUIS B; KRUCZYNSKA D; RAFFLE S. 2004. Synthesis of the central European strawberry cultivar results. Acta Horticulturae 649: $137-140$

LEDESMA NA; NAKATA M; SUGIYAMA N. 2007. Effect of high temperature stress on the reproductive growth of strawberry cvs. "Nyoho" and "Toyonoka". Scientia Horticulturae 166: 186-193.

LI H; LI T; GORDON RJ; ASIEDU SK; HU K. 2010. Strawberry plant fruiting efficiency and its correlation with solar irradiance, temperature and reflectance water index variation. Environmental and Experimental Botany 68: 165-174.

LI M; BADGER J; CHEN X; KWONG S; KEARNEY P; ZHANG H. 2001. An information-based sequence distance and its application to whole mitochondrial genome phylogeny. Bioinformatics 17: 149-154.

LI Y; ZU YQ; CHEN JJ; CHEN HY. 2002. Intraspecific responses in crop growth and yield of 20 soybean cultivars to enhanced ultraviolet-B radiation under field conditions. Field Crops Research 78: 1-8.

LÓPEZ-ARANDA JM; MEDINA JJ; MIRANDA L; BARTUALR; CEBOLLAV; DOMIINGUEZ F; LÓPEZ-MEDINA J. 2002. The Spanish project on alternatives to methyl bromide (1): The case of strawberry in the area of Huelva. Acta Horticulturae 567: 427-430.

MÁRQUEZ JA. 2008. The geographical setting of strawberry fields. In: Junta de Andalucía (ed). The Strawberry Crop at Huelva. p. 47-100.

McKee J; Richards AJ. 1998. The effect of temperature on reproduction in five Primula species. Annals of Botany 82: 359-374.

MIRA DE ORDUÑA R. 2010. Climate change associate effects on grape and wine quality and production. Food Research International 43: 1844-1855.

MORETTI CL; MATTOS LM; CALBO AG; SARGENT SA. 2010. Climate changes and potential impacts on postharvest quality of fruit and vegetable crops: A review. Food Research International 43: 1824-1832.

OKIMURA M; IGARASHI I. 1997. Effects of photoperiod and temperatures on flowering in everbearing strawberry seedlings. Acta Horticulturae 439: 605-607.

PALENCIA P; MARTÍNEZ F; MEDINA JJ; VÁZQUEZ E; FLORES F; LÓPEZ-MEDINA J. 2009. Effect of climate change on strawberry production. Acta Horticulturae 838: 51-54.

RADIN B; LISBOA BB; WITTER S; BARNI $\mathrm{V}$; REISSER JUNIOR C; MATZENAUER R; FERMINO MH. 2011. Desempenho de quatro cultivares de morangueiro em duas regiões ecoclimáticas do Rio Grande do Sul. Horticultura Brasileira 29: 287-291.

RIEGER M. 2005. In: RIEGER M. (eds). Strawberry. Introduction to Fruit Crops. New York: Haworth Food \& Agricultural Products Press, p. 383-392.

SAGE RF; KUBIEN D. 2007. The temperature response of $\mathrm{C} 3$ and $\mathrm{C} 4$ photosynthesis. Plant, Cell \& Environment 30: 1086-1106.

TIRADO MC; CLARKE R; JAYKUS LA; MCQUATTERS-GOLLOP A; FRANK JM. 2010. Climate change and food safety: A review. Food Research International, 43: 1745-1765.

WANG SY; LIN H. 2006. Effect of plant growth temperature on membrane lipids in strawberry (Fragaria x ananassa Duch.). Scientia Horticulturae 108: 35-42.

WATSON JG; ZHU T; CHOW JC; ENGELBRECHT JP; FUJITA EM; WILSON WE. 2002. Receptor modeling application framework for particle source apportionment. Chemosphere 49: 1093-1136.

WOOLFAB; FERGUSON IB; REQUEJO-TAPIA LC; BOYD L; LAING WA; WHITE A. 1999. Impact of sun exposure on harvest quality of 'Hass' avocado fruit. Revista Chaingo Serie Horticultura 5: 352-358.

XU L; ZHANG T. 2007. Influence of light intensity on extracted colour feature of different mature strawberry. New Zealand Journal of Agricultural Research 250: 559565.

YAO Y; XUAN Z; HE Y; LUTOS S; KORPELAINEN H; LI C. 2007. Principal component analysis of intraspecific responses of tartary buckwheat to UV-B radiation under field conditions. Environmental and Experimental Botany 61: 237-245.

ZU YQ; LI Y; CHEN JJ; CHEN HY. 2004. Intraspecific responses in grain quality of 10 wheat cultivars to enhanced UV-B radiation under field conditions. Journal of Photochemistry and Photobiology B 74: 95-100. 